\title{
Identificação bioquímica e molecular das variantes de eliptocitose hereditária: importância da digestão tríptica da espectrina \author{
spectrin tryptic digestion
} \\ Biochemical and molecular identification of variants of heriditary elliptocytosis: importance of
}

Katsue Yasumura
Orientador: Paulo A. Silveira

\section{Resumo}

A eliptocitose hereditária $(\mathrm{EH})$ é uma doença relativamente comum, clínica e geneticamente heterogênea, caracterizada pela presença de um grande número de células vermelhas de forma elíptica, no sangue circulante.Do ponto de vista bioquímico, várias alterações das maiores proteínas do esqueleto da membrana, como a espectrina ( $\mathrm{Sp}$ ) e a proteína 4.1 têm sido observadas na eliptocitose hereditária. Estas alterações incluem anomalias estruturais ou quantitativas nestas proteínas dos eritrócitos afetados. Os defeitos na molécula da espectrina incluem falhas na cadeia $\alpha$ ou $\beta$ e, na maioria dos casos, alterações no domínio $\alpha$ I, a qual é envolvida no processo de auto-associação dos dímeros de espectrina. $\mathrm{O} N$-terminal da $\alpha$ espectina e o C-terminal da cadeia $\beta$ da espectrina são conhecidos por desempenhar um papel importante na auto-associação dos dímeros em tetrâmeros e grandes oligômeros, processo que confere estabilidade ao esqueleto da membrana. Os mutantes do domínio $\alpha$ I da espectrina foram detectados após digestão tríptica limitada da espectrina, revelando a presença de peptídeos originários do domínio normal de $80 \mathrm{kDa}$. Cada variante foi classificada de acordo com o PM e o ponto isoelétrico do peptídeo mutante: $\mathrm{Sp} \alpha \mathrm{I} / 78, \mathrm{Sp} \alpha \mathrm{I} /$ 74, Sp $\alpha \mathrm{I} / 65, \mathrm{Sp} \alpha \mathrm{I} / 46, \mathrm{Sp} \alpha \mathrm{I} / 50 \mathrm{~b}, \mathrm{Sp} \alpha \mathrm{I} / 43$. Em nossos estudos, 6 propositi e 11 familiares com eritrócitos eliptocíticos foram analisados. A digestão tríptica limitada da espectrina, seguida por eletroforese em gel de poliacrilamida (SDS-PAGE), evidenciou concomitantemente uma diminuição do domínio Sp $\alpha \mathrm{I}(80 \mathrm{kDa})$ e a presença de peptídeos anormais com PMs de $65 \mathrm{kDa}$ e $46 \mathrm{kDa}$. Em uma variante estrutural revelada, houve um aumento do peptídeo de $74 \mathrm{kDa}$, sem alterações no domínio $\alpha \mathrm{I}$. O polimorfismo va 41, de baixo expressão foi também encontrado em um propositus e em sua mãe. Todas essas variantes de espectrina impossibilitam o processo de auto-associação para formação dos tetrâmeros e dos oligômeros, um processo que é dependente de um domínio $\alpha \mathrm{I}$ intacto e que é importante na formação da rede composta de espectrina-actina-proteína 4.1 na superfície interna da membrana do glóbulo vermelho.

Palavras-chave: Eliptocitose; espectrina; identificação; digestão tríptica.

\begin{abstract}
Hereditay elliptocytosis (HE) is a relatively common, clinically and genetically heterogenous disorder, characterized by the presennce of a large number of ellypticlly-shaped red blood cells in the peripheral blood.From the biochemical point of view, several alterations of the major membrane skeleton proteins such as spectrin ( $\mathrm{Sp}$ ) and protein 4.1 have been observed, influencing the structure or quantity of these proteins in affected erythrocytes. Defects within the Sp molecule include shortening of the $\alpha$ or $\beta$ chain and, in most cases, alterations in the Sp-dimer self-association process. The $\mathrm{N}$ terminus of $\alpha$-spectrin and the $\mathrm{C}$ terminus of $\beta$ spectrin are known to play important roles in the self-association of spectrin dimers into tetramers and larger oligomers, a phenomenon that confers stability to the membrane skeleton. Sp $\alpha$ I domain mutants have been detected after limited tryptic digestion of $\mathrm{Sp}$, which shows the presence of peptides derived from the normal $\alpha$ I domain of $80 \mathrm{kDa}$. Each variant has been classified according to the molecular weight and isoelectric point of the abnormal peptide: $\operatorname{Sp} \alpha \mathrm{I} / 78, \operatorname{Sp} \alpha \mathrm{I} / 74, \operatorname{Sp} \alpha \mathrm{I} / 65, \operatorname{Sp} \alpha \mathrm{I} / 46, \operatorname{Sp} \alpha \mathrm{I} /$ $50 \mathrm{~b}$ and $\mathrm{Sp} \alpha \mathrm{I} / 43$. In this study, six propositi and eleven family members with elliptocytic red cells were evaluated. Limited tryptic digestion of spectrin, followed by sodium dodecyl sulfate polyacrylamide gel electrophoresis (SDS-PAGE) revealed both a decrease in the $\alpha \mathrm{I}$ domain $(80 \mathrm{kDa})$ and the presence of abnormal peptides with molecular weights of $65 \mathrm{kDa}$ and $46 \mathrm{kDa}$. In one structural variant, there was an increase in a $74 \mathrm{kDa}$ peptide, without alterations in the $\alpha I$ domain. The vo 41 polymorphism, with a lowexpression, was also encountered in one propositus and her mother. All of these spectrin variants inhibit self-association to form tetramers and higher oligomers, a process that is known to be dependent upon an intact $\alpha$ I domain, and one which is thought to be important in the formation of the spectrin-actin-4.1 network on the inner surface of the red blood cell membrane.
\end{abstract}

Key words: Elliptocytosis, spectrin, identification, tryptic digestion.

Avaliação: A RBHH publica os resumos e abstracts de teses da área apresentados em entidades que tenham programas de pós-graduação reconhecidos pelo MEC/Capes e considera a obtenção do título suficiente para sua publicação na forma como se propõe a seção.

Recebido: 12/05/2008; Aceito: 14/05/2008

Tese de dissertação para obtenção do título de Mestre em Farmácia, área de Análises Clínicas. Faculdade de Ciências Farmacêuticas,USP-SP.

Correspondência: Katsue Yasumura

Av. Dr. Enéas Carvalho de Aguiar, 155, $1^{\circ}$ andar - Cerqueira César - 05403-000 - São Paulo-SP - Brasil

E-mail:kyasumura@bol.com.br 